\title{
PREPARATION OF EXPERIMENTAL SAGGER BODIES ACCORDING TO FUNDAMENTAL PROPERTIES
}

\author{
By R. A. Heindl and L. E. Mong
}

\section{ABSTRACT}

This report presents the results obtained in a preliminary study of sagger bodies and contains data on the modulus of elasticity, transverse breaking strength, plastic flow, thermal expansion, and resistance to failure due to heat shock of $\mathbf{5 5}$ sagger mixes representing 39 different bodies fired at either $1,230^{\circ}$ or $1,270^{\circ} \mathrm{C}$. The 16 bodies prepared in duplicate were tested both after firing at $1,230^{\circ}$ and $1,270^{\circ}$ C. The bodies were prepared from a total of 15 different clays of known properties, and each body was made from two clays and a mixture of graded grog. The grog was graded into sizes so as to result in two types of bodies, those having (1) a coarse and open-grained structure and (2) a dense and fine-grained structure. The data on the fired bodies show that those containing the fine sizes of grog have the higher modulus of elasticity, transverse strength, and in the majority of cases, thermal expansion. Very little difference in total porosity of the two types of bodies is indicated although the rate of absorption shows great differences. The data obtained in this preliminary study indicate that those bodies having a porosity of less than 25 per cent, a low modulus of elasticity, as high transverse strength as is compatible with the low modulus of elasticity, and low thermal expansion below $250^{\circ} \mathrm{C}$. are the most desirable for sagger purposes.

\section{CONTENTS}

Page

I. Introduction

II. General

III. Sagger body compositions

IV. Description of specimens

V. Methods of testing and results

1. Modulus of rupture, unfired bodies

2. Porosity

3. Linear thermal expansion

4. Modulus of elasticity and transverse strength

5. Plastic flow

6. Air quenching or dunting tests

7. Relation between porosity and dunting

7. Relation between porosity and dunting.

8. Effect of thermal expansion on dunting

9. Modulus of elasticity, expansion, transverse strength, porosity, and resistance to dunting . . .

10. Extreme fiber deformation

11. Commercial sagger bodies 


\section{INTRODUCTION}

The investigation of the properiies of sagger clays and sagger bodies is a study which readily resolves itself into a number of phases, each of which is more or less complete in itself. Results obtained in the study at the Bureau of 'Standards of several of these individual phases have been previously reported. ${ }^{1}$ The present paper describes recent studies which included the preparation of sagger bodies based on fundamental data, the making of small experimental saggers, and the determination of certain physical properties of the fired saggers and sagger bodies. It contains the results of tests made on 39 different sagger bodies prepared in the laboratory and on eight sagger bodies furnished by pottery manufacturers as well as on saggers made from all these bodies.

\section{GENERAL}

A study of the sagger body compositions used by 40 pottery and tile manufacturers shows a large variation in the number and percentages of different clays used and percentage and sizing of grog. It also shows that the "rule-of-thumb" practice is largely followed in the compounding of sagger bodies. The number of clays used in any one body varies from two to four, and the amount of grog in the various bodies ranges from approximately 30 to 60 per cent. The majority of sagger mixes fail to show any definite sizing or grading of grog. In some cases the grog is simply crushed to pass a sieve with fairly large openings, while in others only the coarse grog is used. In general, the raw clay content of most sagger mixtures consists of one or more dense firing or vitrifying clays and one or more open-burning and comparatively refractory clays, with varying percentages and sizes of grog.

The possible variations in clay combinations, sizing, percentage, and porosity of grog's and firing temperatures is practically unlimited with the many sagger clays on the market. It was, therefore, necessary to limit this study to the making and testing of such body compositions from the 17 representative clays as might result in data of most value for preparing saggers of maximum life.

1 I. Progress Report on Investigation of Sagger Clays, J. Am. Ceram. Soc., 9 (3), pp. 131-143; 1926. II. Progress Report on Investigation of Sagger Clays-Some Observations as to the Significance of Their Thermal Expansion, J. Am. Ceram. Soc., 9 (9), pp. 554-574; 1926. III. Progress Report on Investigation of Sagger Clays-Their Elasticity and Transverso Strength at Several Temperatures, J. Am. Ceram. Soc., 10 (7), pp. 524-534; 1927. IV. Progress Report on Investigation of Sagger Clays-Their Elasticity, Transverse Strength, and Plastic Flow at 1,000 C., J. Am. Ceram. Soc., 10 (12), pp. 995-1004; 1927. 


\section{SAGGER BODY COMPOSITIONS}

The initial study of the compounding of sagger bodies included the blending of two clays, in equal parts by weights, mixed with equal proportions by weight of grog prepared from each clay. One of the clays when fired had a high porosity (open-burning) and the other a somewhat lower porosity (close-burning). The grogs used in these mixes were fired at approximately $1,230^{\circ} \mathrm{C}$. (cone 9-9 $\frac{1 / 2}{2}$ ) for one and one-half hours. This procedure was varied in several instances by using separately grog prepared from only one of the clays; that is, either the open-burning or the dense-burning clay. With one exception, only clays having the same general type of thermal expansion below $200^{\circ} \mathrm{C}$. were used in a body; that is, each of the clays making up a body was taken from either group $\mathrm{H}$ or group L. ${ }^{2}$ The sagger body numbers, the clays and grogs making up the various bodies, and the properties of these clays fired at $1,230^{\circ} \mathrm{C}$. are given in Table 1.

The majority of the bodies were prepared in two series as similar as possible in every respect with the exception of the sizes of the grog. One series compounded with comparatively coarse sizes of graded grog was designated as " $\mathrm{C}$ " and the other series compounded with the finer sizes of graded grog was designated as "F." Two combinations of grog sizes were taken from those recommended by Kirkpatrick. ${ }^{3}$ The one, consisting of the relatively coarser sizes of grog, is recommended where resistance to repeated heating and cooling is desired more than strength. In the other, finer sizes are used and resistance to repeated thermal shock is sacrificed to obtain bodies of greater strength.

In the two primary combinations used, the grog sizing and the percentage of each size are as follows:

\begin{tabular}{|c|c|c|c|}
\hline \multirow{2}{*}{ Material } & \multicolumn{2}{|c|}{ Sieve No. } & \multirow{2}{*}{$\begin{array}{l}\text { Percent } \\
\text { age of } \\
\text { each } \\
\text { size }\end{array}$} \\
\hline & Passed- & $\begin{array}{c}\text { Retained } \\
\text { on- }\end{array}$ & \\
\hline For coarse grogged body & $\begin{array}{r}4 \\
8 \\
12\end{array}$ & $\begin{array}{r}8 \\
12 \\
20\end{array}$ & $\begin{array}{l}20 \\
60 \\
20\end{array}$ \\
\hline For fine grogged body.- & $\begin{array}{l}20 \\
40\end{array}$ & $\begin{array}{l}40 \\
80\end{array}$ & $\begin{array}{l}662 / 3 \\
331 / 3\end{array}$ \\
\hline
\end{tabular}

2 Report II (footnote 1) states that the clays have been classed in two groups according to thermal expansion behavior between $100^{\circ}$ and $200^{\circ} \mathrm{C}$.; clays classed in Group L showed a decided increase in the rate of expansion, while clays of Group $\mathrm{H}$ showed a very small, or, in the majority of cases, no increase in rate of expansion.

${ }^{3}$ B. S. Tech. Paper No. 104, p. 38, Table 11.

$$
64338^{\circ}-29-6
$$


TABLE 1.-Data on clays ${ }^{1}$ fired at $1,230^{\circ}$ C. used in sagger bodies

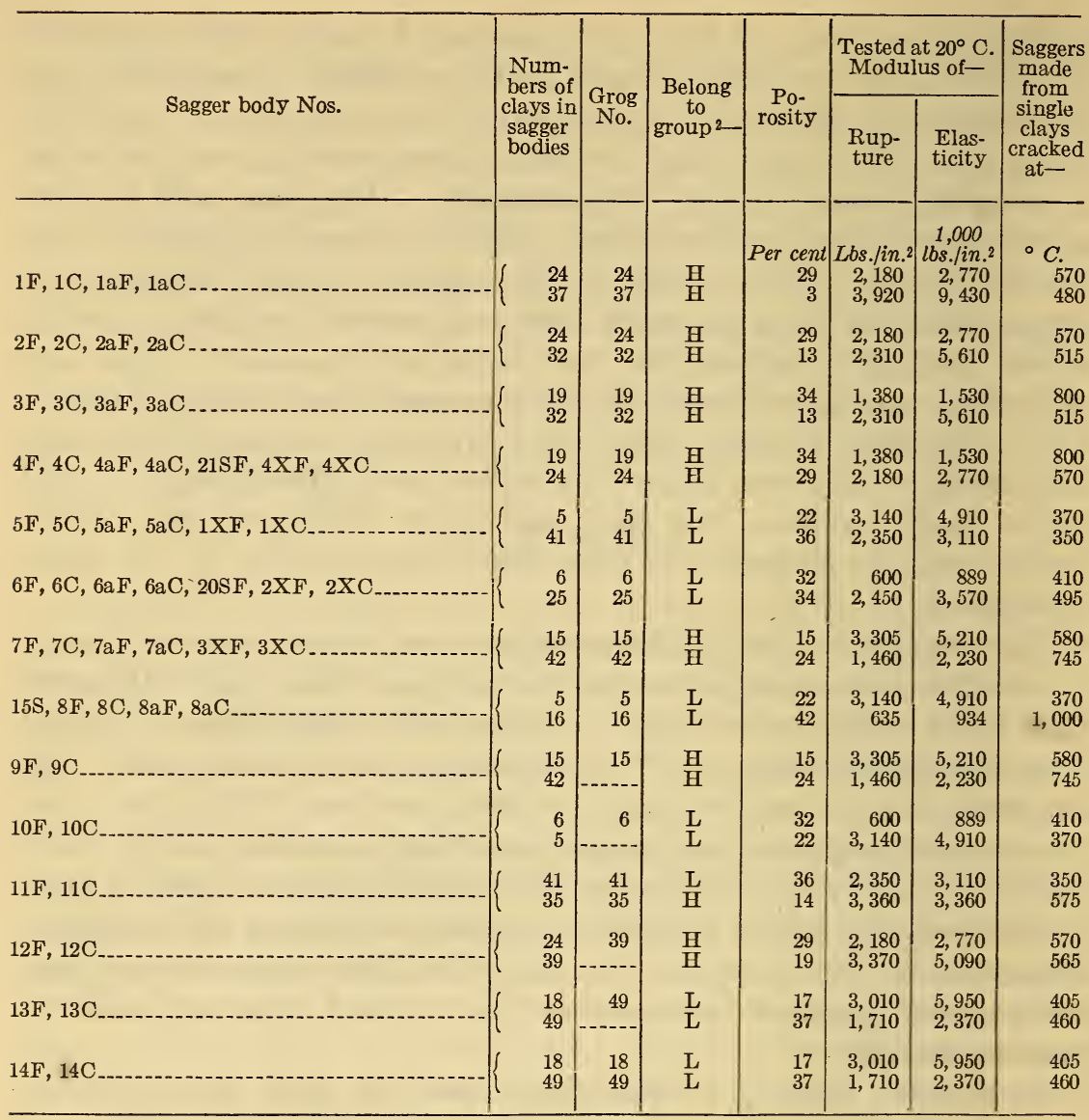

1 Complete chemical and physical properties of these clays have been given in the four progress reports already published on this investigation. (See footnote 1 of text.)

${ }_{2}$ The second progress report (see footnote 1 of text) classed the clays according to rate of thermal expansion below $200^{\circ} \mathrm{C}$. into Groups H and L.

The following special combinations of grog were used in one body each ("S" bodies):

1. Body 15S. Grog and dust passing an 80-mesh sieve.

2. Body 21S. F. Grog graded as follows to obtain a dense and strong body:

\begin{tabular}{|c|c|c|}
\hline \multicolumn{2}{|c|}{ Sieve No. } \\
\cline { 1 - 2 } Passed- & $\begin{array}{c}\text { Retained } \\
\text { on- }\end{array}$ & \\
& $\begin{array}{c}\text { Percent- } \\
\text { age used }\end{array}$ \\
\hline 20 & 40 & 40 \\
40 & 80 & 20 \\
80 & 200 & 40 \\
\hline
\end{tabular}


3. Body 20S. F. Grog approximately graded in accordance with W. F. Fuller's curve ${ }^{4}$ to obtain a body especially resistant to thermal shock and also of good strength.

\begin{tabular}{|c|c|c|}
\hline \multicolumn{2}{|c|}{ Sieve No. } & \multirow{2}{*}{$\begin{array}{c}\text { Percent- } \\
\text { age of } \\
\text { each size }\end{array}$} \\
\cline { 1 - 2 } Passed- & $\begin{array}{c}\text { Retained } \\
\text { on- }\end{array}$ & \\
\hline 4 & 8 & 20 \\
8 & 12 & 15 \\
12 & 20 & 20 \\
20 & 40 & 15 \\
40 & 80 & 15 \\
80 & 200 & 15 \\
\hline
\end{tabular}

In addition, eight bodies were prepared, four each using the coarse and fine grog combinations, except that the grog was fired for one and one-half hours at $770^{\circ} \pm 5^{\circ} \mathrm{C}$., instead of $1,230^{\circ} \mathrm{C}$. These bodies (" $\mathrm{X}$ " bodies) were so prepared because it has been found that fire clays show a rapid contraction at about $800^{\circ}$ C..$^{5}$ It was assumed that it might be desirable to use grog which has not been fired higher than this temperature so as to eliminate the strains which are likely to be set up between the bond and grog during firing if the latter had been first fired at a temperature considerably higher than $800^{\circ} \mathrm{C}$.

\section{DESCRIPTION OF SPECIMENS}

The grog used in the preparation of specimen bars and saggers had been fired in all cases to approximately $1,230^{\circ}$ C. (cone 91/2). Six bars 1 by 1 by 12 inches were prepared for the determination of modulus of elasticity and transverse strength. Specimens measuring approximately 1 by 1 by 6 inches were used for linear thermal expansion studies. These specimens were cut to size from the ruptured 1 by 1 by 12 inch bars used for modulus of elasticity determinations. Six specimens 1 by 1 by 7 inches were made for dry breaking-strength tests and five (in some cases six) saggers, 4 by 4 by 6 by $1 / 2$ inches, were made for the thermal-shock test. The saggers were made oval in shape to more nearly simulate the conditions producing strains developed in saggers used in practice. One set of saggers and the 12-inch bars were fired at approximately $1,230^{\circ} \mathrm{C}$. (cones 9-91/2) and another set of each at $1,270^{\circ} \mathrm{C}$. (cones $11 \frac{1 / 2}{2}-12$ ). To simulate industrial conditions which might cause some difference in the properties of the burned bodies, the saggers of any one set were not all made on the same day but on different days. All saggers were fired in the same kiln, a part of each set of five saggers being fired at different times.

4 Concrete Plain and Reinforced, 1916 ed., by Taylor and Thompson.

$\checkmark$ The Behavior of Fire Clays, Bauxites, etc., on Heating, Trans. Eng. Cer. Soc., 22, p. 111; 1922-23. 


\section{METHODS OF TESTING AND RESULTS}

The methods of determining the modulus of rupture, porosity, linear thermal expansion, resistance to thermal shock, modulus of elasticity, and transverse strength at room and elevated temperatures, and the plastic flow at $1,000^{\circ} \mathrm{C}$., have been described in detail in the several previous reports. ${ }^{6}$ It might be well, however, again to give briefly the method used in the quenching test. Five specimen saggers of each of the bodies were heated at progressively higher temperatures and air quenched until fracture occurred. The initial quenching was from $350^{\circ} \mathrm{C}$., the second $400^{\circ} \mathrm{C}$., and for each succeeding quenching the temperature was increased $25^{\circ} \mathrm{C}$. until the test sagger failed.

\section{MODULUS OF RUPTURE, UNFIRED BODIES}

The moduli of rupture of the various sagger bodies, both those prepared in the laboratory and those received from the potteries, are given in Tables 2 and 3.

The average modulus of rupture for the bodies containing the fine grog was found to be $160 \mathrm{lbs}$./in. ${ }^{2}$, for the bodies containing the coarse grog $95 \mathrm{lbs}$./in. ${ }^{2}$, and for the commercial bodies $75 \mathrm{lbs}$./in. ${ }^{2}$. 


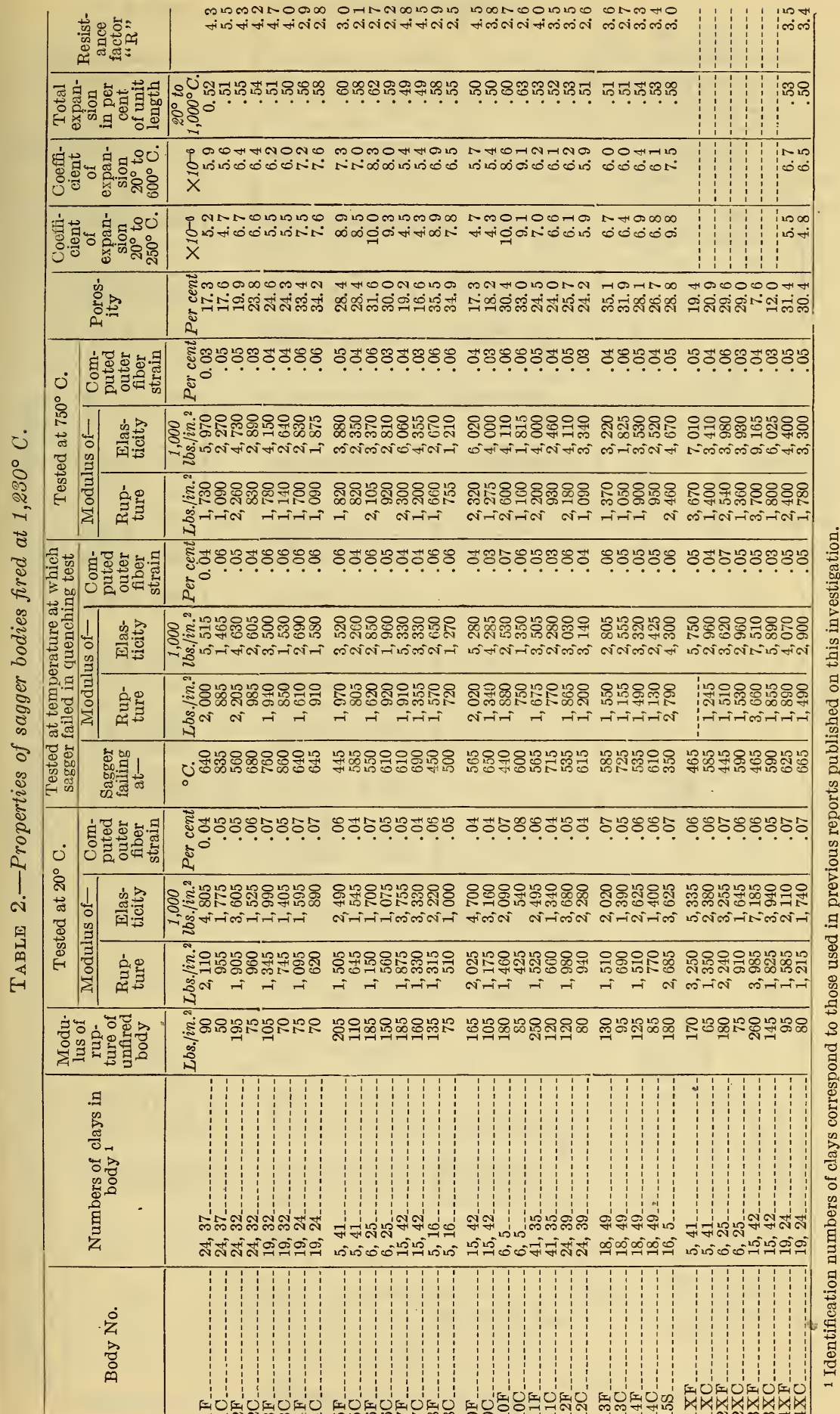




\begin{tabular}{|c|c|c|c|}
\hline \multicolumn{3}{|c|}{ 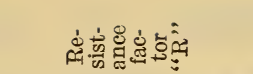 } & $\begin{array}{ll}\overrightarrow{1} & 0 \\
\dot{m} & \dot{\mathrm{N}}\end{array}$ \\
\hline \multicolumn{3}{|c|}{ 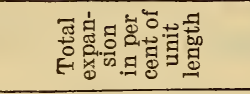 } & 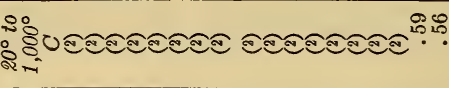 \\
\hline \multicolumn{3}{|c|}{ 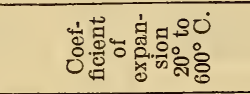 } & 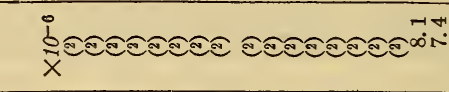 \\
\hline \multicolumn{3}{|c|}{ 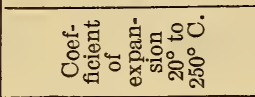 } & 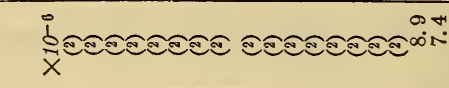 \\
\hline \multicolumn{3}{|c|}{ की } & 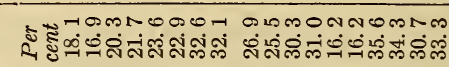 \\
\hline \multirow{4}{*}{ 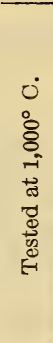 } & \multirow{2}{*}{ 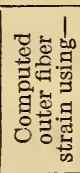 } & 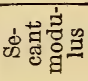 & 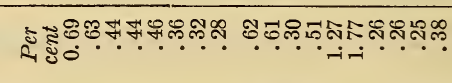 \\
\hline & & 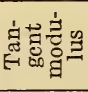 & 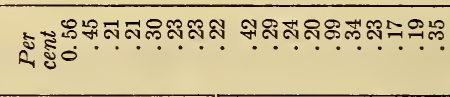 \\
\hline & \multirow{2}{*}{ 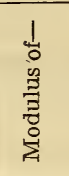 } & 密勇 & 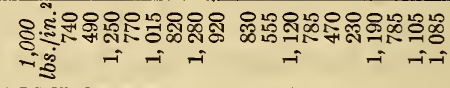 \\
\hline & & 象总 & 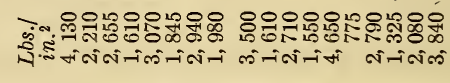 \\
\hline \multirow{3}{*}{ 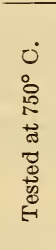 } & \multicolumn{2}{|c|}{ 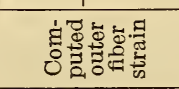 } & 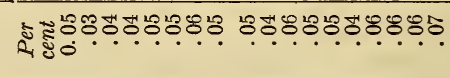 \\
\hline & \multirow{2}{*}{ 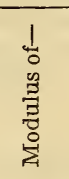 } & 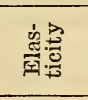 & 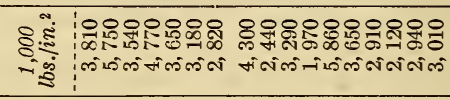 \\
\hline & & ف욣 & 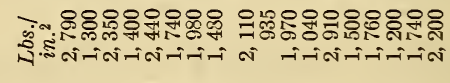 \\
\hline \multirow{4}{*}{ 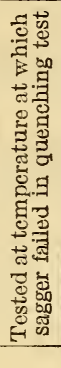 } & \multicolumn{2}{|c|}{ 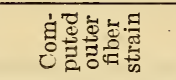 } & 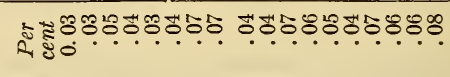 \\
\hline & \multirow{2}{*}{ 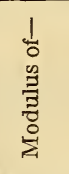 } & 㝑总 & 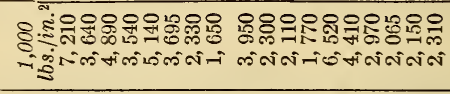 \\
\hline & & 密苟 & 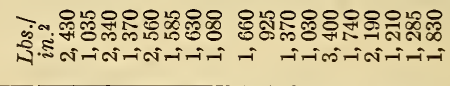 \\
\hline & \multicolumn{2}{|c|}{ 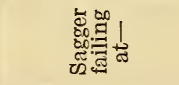 } & 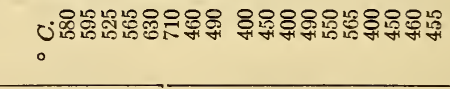 \\
\hline \multirow{3}{*}{ 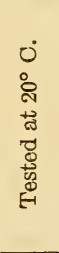 } & \multicolumn{2}{|c|}{ 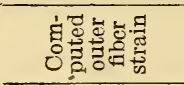 } & 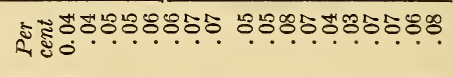 \\
\hline & \multirow{2}{*}{ 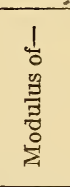 } & 谣总 & 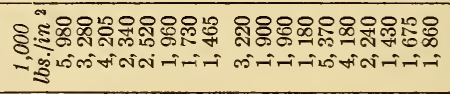 \\
\hline & & 实号 & 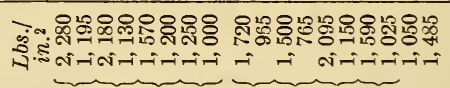 \\
\hline \multicolumn{3}{|c|}{ 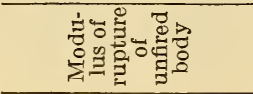 } & 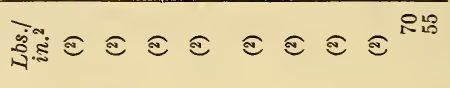 \\
\hline \multicolumn{3}{|c|}{ 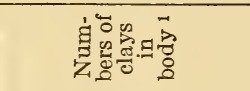 } & 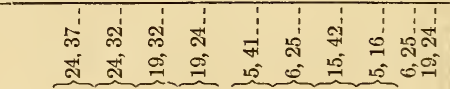 \\
\hline \multicolumn{3}{|c|}{ कृष्ठ } & \\
\hline
\end{tabular}

Nommonmo

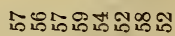

○.........

nommonom

NiNiñö

1000 ONNONOH

$\left.\infty \infty^{\circ} 0^{\circ} 0^{\circ} \infty 0^{\circ} \infty\right)^{\circ}$

$m$-n 00000

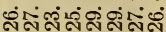

ริำ $\circ$

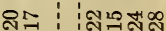

$\dot{0} \cdot \cdots$

앙유

$\rightarrow$ :

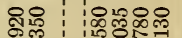

in :intiti

푸요

政

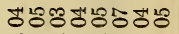

$\circ \cdot \cdots \cdot$

유으매.

mintintin

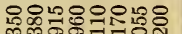
تiनi rifititi

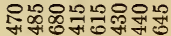

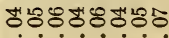
$\circ$

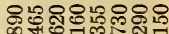

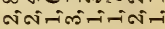

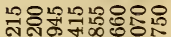
i-i i

잉요

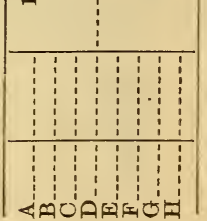




\section{POROSITY}

The porosities of the sagger bodies fired at $1,230^{\circ} \mathrm{C}$. are given in Table 2 and those of the bodies fired at $1,270^{\circ} \mathrm{C}$. are given in Table 3. The range in porosity, for the bodies fired at $1,230^{\circ} \mathrm{C}$., is from approximately 8 to 35.5 per cent and for the bodies fired at $1,270^{\circ}$ C. from 16 to 35.6 per cent. As shown earlier in this report, there is considerable difference in the sizes of the grog used in the preparation of coarse and fine grogged bodies. A macroscopic examination of the texture of the sagger bodies also shows a decided difference in structure of the fine and coarse grogged bodies. In practically all cases, very little difference in porosity was found for any pair of bodies of the same key number whether the grog was fine or coarse grained. Consequently, the relative pore size of the fine and coarse grogged sagger bodies was determined by measuring the rate of absorption of the bodies after complete immersion in water at room temperature for certain time intervals, namely 5 minutes, 1 hour, and 48 hours. The results given in Table 4 of the tests made on specimen bars, show great differences in porosity of bodies fired at $1,270^{\circ} \mathrm{C}$.

TABLE 4.-Rate of absorption (pore size) in terms of porosity (bodies fired at $1,270^{\circ} \mathrm{C}$.)

\begin{tabular}{|c|c|c|c|c|c|c|c|c|c|}
\hline \multirow{2}{*}{ Body No. } & \multicolumn{3}{|c|}{$\begin{array}{l}\text { Results obtained after } \\
\text { immersing specimens- }\end{array}$} & \multirow{2}{*}{$\begin{array}{l}\text { Total } \\
\text { poros- } \\
\text { ity }\end{array}$} & \multirow{2}{*}{ Body No. } & \multicolumn{3}{|c|}{$\begin{array}{l}\text { Results obtained after } \\
\text { immersing specimens- }\end{array}$} & \multirow{2}{*}{$\begin{array}{l}\text { Total } \\
\text { poros- } \\
\text { ity }\end{array}$} \\
\hline & 5 min- & 1 hour & 48 hours & & & 5 min- & 1 hour & 48 hours & \\
\hline $\begin{array}{l}1 \mathrm{aF} \\
1 \mathrm{aC}- \\
2 \mathrm{aF} \\
2 \mathrm{aC} . \\
3 \mathrm{aF}\end{array}$ & $\begin{array}{r}\text { Per ct. } \\
3.83 \\
9.53 \\
2.84 \\
12.60 \\
7.55\end{array}$ & $\begin{array}{r}\text { Per ct. } \\
6.55 \\
9.64 \\
5.60 \\
12.50 \\
14.75\end{array}$ & $\begin{array}{r}\text { Per ct. } \\
7.60 \\
10.45 \\
9.56 \\
15.65 \\
16.85\end{array}$ & $\begin{array}{r}\text { Per ct. } \\
16.1 \\
17.6 \\
18.8 \\
18.5 \\
24.8\end{array}$ & $\begin{array}{l}7 \mathrm{aF} \\
7 \mathrm{aC}\end{array}$ & $\begin{array}{r}\text { Per } c t . \\
17.25 \\
22.30 \\
2.43 \\
8.75\end{array}$ & $\begin{array}{r}\text { Per ct. } \\
24.32 \\
22.95 \\
4.82 \\
8.72\end{array}$ & $\begin{array}{r}\text { Per ct. } \\
25.90 \\
26.76 \\
7.15 \\
9.55\end{array}$ & $\begin{array}{r}\text { Per ct. } \\
31.9 \\
31.7 \\
15.2 \\
15.7\end{array}$ \\
\hline $\begin{array}{l}4 a C- \\
5 a F- \\
5 a C-\end{array}$ & $\begin{array}{l}12.68 \\
17.54 \\
25.03 \\
13.98 \\
17.25\end{array}$ & $\begin{array}{l}13.91 \\
26.25 \\
25.32 \\
14.32 \\
17.08\end{array}$ & $\begin{array}{l}17.95 \\
28.17 \\
28.00 \\
17.12 \\
18.52\end{array}$ & $\begin{array}{l}24.5 \\
32.4 \\
31.3 \\
25.6 \\
25.1\end{array}$ & $\begin{array}{l}20 \mathrm{~S} \\
21 \mathrm{~S}\end{array}$ & $\begin{array}{l}20.20 \\
26.80 \\
18.83 \\
16.00\end{array}$ & $\begin{array}{l}27.90 \\
26.70 \\
24.85 \\
27.95\end{array}$ & $\begin{array}{l}29.30 \\
28.75 \\
27.00 \\
29.65\end{array}$ & $\begin{array}{l}34.6 \\
33.3 \\
31.2 \\
33.8\end{array}$ \\
\hline
\end{tabular}

\section{IINEAR THERMAL EXPANSION}

The average coefficient of linear expansion between $20^{\circ} 7$ and $250^{\circ} \mathrm{C}$., $20^{\circ}$ and $600^{\circ} \mathrm{C}$., and also the total expansion at $1,000^{\circ} \mathrm{C}$. in per cent of unit length are given in Table 2 for the specimens fired at $1,230^{\circ} \mathrm{C}$., and in Table 3 for certain specimens fired at $1,270^{\circ} \mathrm{C}$. The results obtained on the 30 bodies fired at $1,230^{\circ} \mathrm{C}$. indicate that, when blending two clays and grog prepared from either one or both clays, the resulting expansion behavior of the mixture may fall into one of the three following classes:

1. It may be greater than the expansion of either clay contained in the body. In this group are included bodies Nos. $2 \mathrm{~F}, 2 \mathrm{C}, 4 \mathrm{~F}$, $4 \mathrm{C}, 12 \mathrm{~F}$, and $12 \mathrm{C}$.

\footnotetext{
7 The average room temperature was approximately $20^{\circ} \mathrm{C}$. during these experiments.
} 
2. It may be approximately equal to the average expansion of the clays making up the body. This group contains bodies Nos. $3 \mathrm{~F}, 3 \mathrm{C}$, $4 \mathrm{XF}, 4 \mathrm{XC}, 6 \mathrm{~F}, 6 \mathrm{C}, 10 \mathrm{~F}, 10 \mathrm{C}, 11 \mathrm{~F}$, and $11 \mathrm{C}$.

3. It may be approximately the same as that of the clay in the body having the lower expansion. Bodies Nos. $1 \mathrm{~F}, 1 \mathrm{C}, 5 \mathrm{~F}, 5 \mathrm{C}, 7 \mathrm{~F}$, $7 \mathrm{C}, 8 \mathrm{~F}, 8 \mathrm{C}, 9 \mathrm{~F}, 9 \mathrm{C}, 13 \mathrm{~F}, 13 \mathrm{C}, 14 \mathrm{~F}$, and $14 \mathrm{C}$ are in this group.

An illustration of the expansion behavior of bodies grouped in class 1 is shown on the left in Figure 1. Full line curves represent the linear thermal expansion from $20^{\circ}$ to $1,000^{\circ} \mathrm{C}$. of each of the two clays used in the preparation of bodies Nos. $4 \mathrm{~F}$ and $4 \mathrm{C}$, and broken lines those obtained on these bodies. The curves for the bodies are practically identical in this instance. Since all the bodies in class 1 contain clay No. 24, it would appear that this clay when blended with another clay and the grog made from it produces no effect on the thermal expansion of the blend fired at $1,230^{\circ} \mathrm{C}$. Although bodies $4 \mathrm{XC}$ and $4 \mathrm{XF}$ have an expansion behavior similar to those grouped in class 2, the expansion curves are shown in the left section of Figure 1 to facilitate comparison with the curves for bodies $4 \mathrm{C}$ and $4 \mathrm{~F}$. Bodies $4 \mathrm{XF}$ and $4 \mathrm{XC}$ are identical in every respect with bodies Nos. $4 \mathrm{~F}$ and $4 \mathrm{C}$, respectively, except that the grog used in the former had been fired to approximately $775^{\circ} \mathrm{C}$. instead of $1,230^{\circ} \mathrm{C}$. Due to the comparative softness of the grog fired at $775^{\circ} \mathrm{C}$., it disintegrated somewhat during mixing with the clays and pugging of the body which caused a more intimate mixture of clays and grog than if the grog had been fired at a considerably higher temperature. This, together with the fact that the clay as grog had not altered as much in its physical properties when fired at $775^{\circ} \mathrm{C}$. as when fired at $1,230^{\circ} \mathrm{C}$., probably was the cause of a more complete reaction occurring between the constituents in the clay and grog which resulted in an expansion approximately the average of the two individual clays.

An example of the expansion of bodies grouped in class 2 is shown in the center section of Figure 1. The curves given were obtained on bodies $10 \mathrm{~F}$ and $10 \mathrm{C}$ which were prepared from clays Nos. 5 and 6 and grog made from these clays. The expansion curves for the individual clays are also shown.

To the right in Figure 1 are given the expansion curves of bodies $14 \mathrm{~F}$ and $14 \mathrm{C}$, which are included in class 3 . These bodies were made of clays Nos. 18 and 49, and grog from the same clays fired at $1,230^{\circ} \mathrm{C}$. The thermal expansion curves for the individual clays, also given, show a large difference in total expansion. Since the expansions of the bodies closely approach the lower and more desirable expansion of clay No. 18, it would indicate that the selection of clays as far as this property is concerned was favorably made. Apparently most clays blended as in this study act favorably with respect 


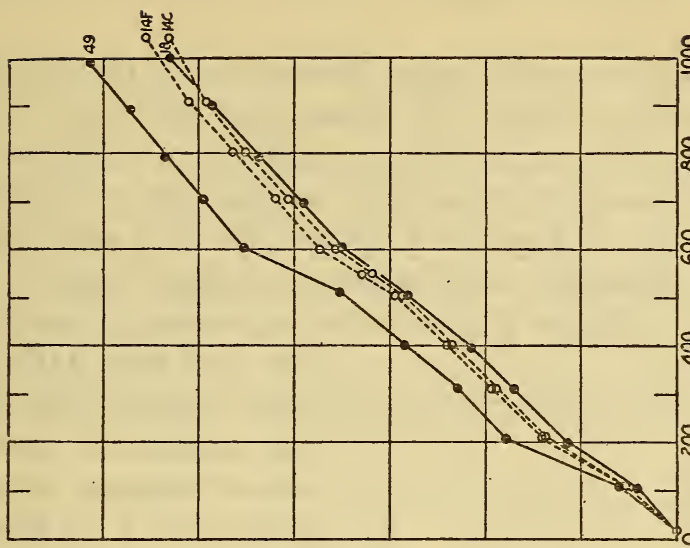

요으

8

8

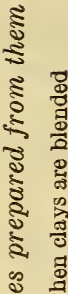

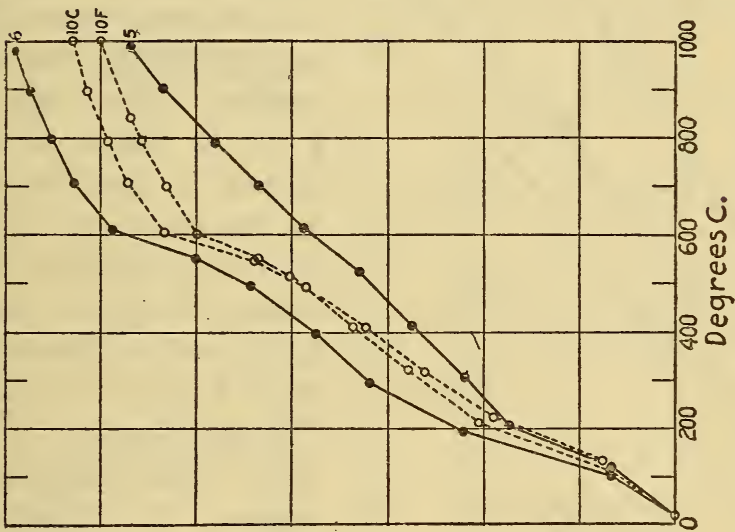

:3

몽

굴

है

공

3)

. సี

:

ป ङ

8 है

s

$\infty$ 当

ปี

เ

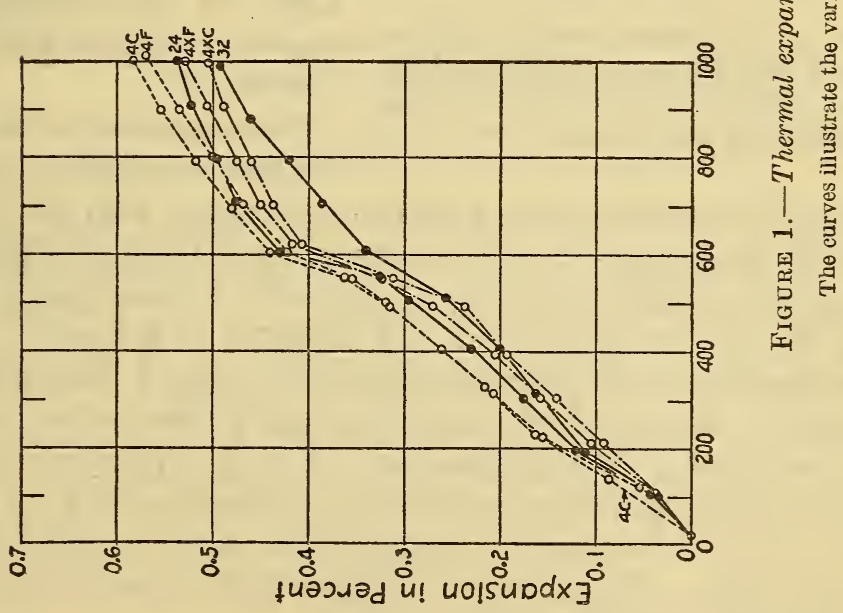


to the thermal expansion since the majority of bodies are classed in this group.

Table 1 shows that all bodies except Nos. $11 \mathrm{~F}$ and $11 \mathrm{C}$ were prepared from clays having the same general type of expansion; that is, both were classed in either group $\mathrm{H}$ or $\mathrm{L}$. Bodies Nos. $11 \mathrm{~F}$ and $11 \mathrm{C}$ were prepared with clay No. 35 from group $\mathrm{H}$ (uniform and relatively low rate of expansion below $200^{\circ}$ C.) and clay No. 41 from group $L$ (irregular and relatively higher rate of expansion below $200^{\circ}$ C.). Figure 2 shows the expansion curves for bodies Nos. $11 \mathrm{~F}$ and $11 \mathrm{C}$ as well as

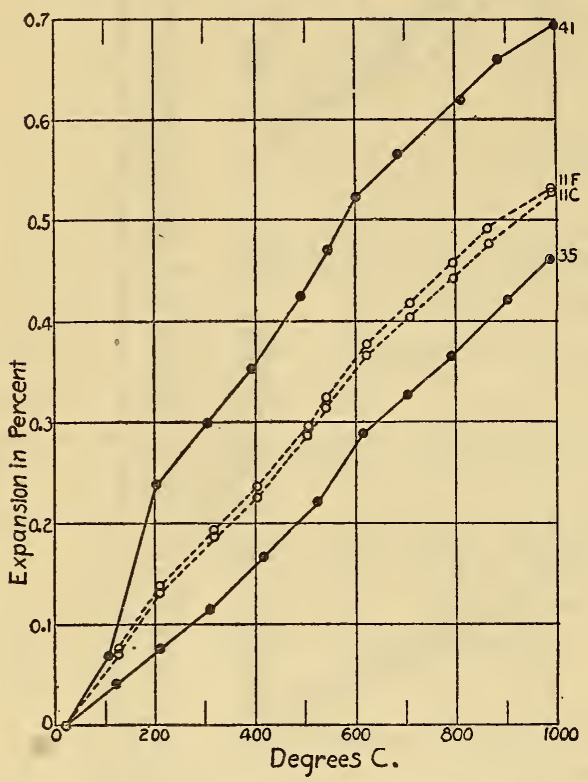

FIGURE 2.- Showing widely different types of thermal expansion curves of two clays (full lines) and of the two bodies in which they were blended those of clays Nos. 35 and 41. The expansion curves of the bodies illustrate what may be accomplished by blending two clays having a very large difference in total expansion as well as entirely different rates of expansion below $200^{\circ} \mathrm{C}$. The P. C. E. values of clays Nos. 35 and 41 are 20-26 and 3031 , respectively. Any reaction occurring between these clays during firing was undoubtedly facilitated by the comparatively low P.C. E. value of clay No. 35 . The combination of these two clays was decidedly advantageous in eliminating the high and unfavorable rate of expansion of clay No. 41 below $200^{\circ} \mathrm{C}$.

A comparison of the thermal expansion curves of the bodies containing the coarser grog with those prepared with the finer grog shows that the expansion of the coarse-grogged bodies is slightly lower than the fine-grogged bodies in 67 per cent of those tested, approximately the same in 20 per cent, and higher in 13 per cent.

A comparison of the thermal expansion curves of the sagger bodies with those of the two clays composing each of the bodies shows that out of the total of 15 combinations, 12 were advantageously made with respect to the thermal expansion of either one or both clays.

Check determinations of expansions were made on eight specimens of sagger bodies. The greatest variation in the data obtained on the same body was less than $\pm 2 \frac{1}{2}$ per cent. 


\section{MODULUS OF ELASTICITY AND TRANSVERSE STRENGTH}

The deflections corresponding to various loads applied to body $20 \mathrm{SF}$ are plotted in Figure 3. Results obtained at 20, 460 (the temperature at which the sagger failed in the heat shock test), and $750^{\circ} \mathrm{C}$. are plotted to illustrate the increase in resistance to bending of sagger bodies as the temperature within these limits is increased.

Bodies fired at $1,230^{\circ} \mathrm{C}$.- The modulus of elasticity and transverse breaking strength (modulus of rupture) of 37 bodies, including 8 containing the grog fired at $775^{\circ} \mathrm{C}$. and 1 containing grog and dust passing through a No. 80 sieve, were determined at room temperature, at the temperature of failure in an air-quenching test of saggers

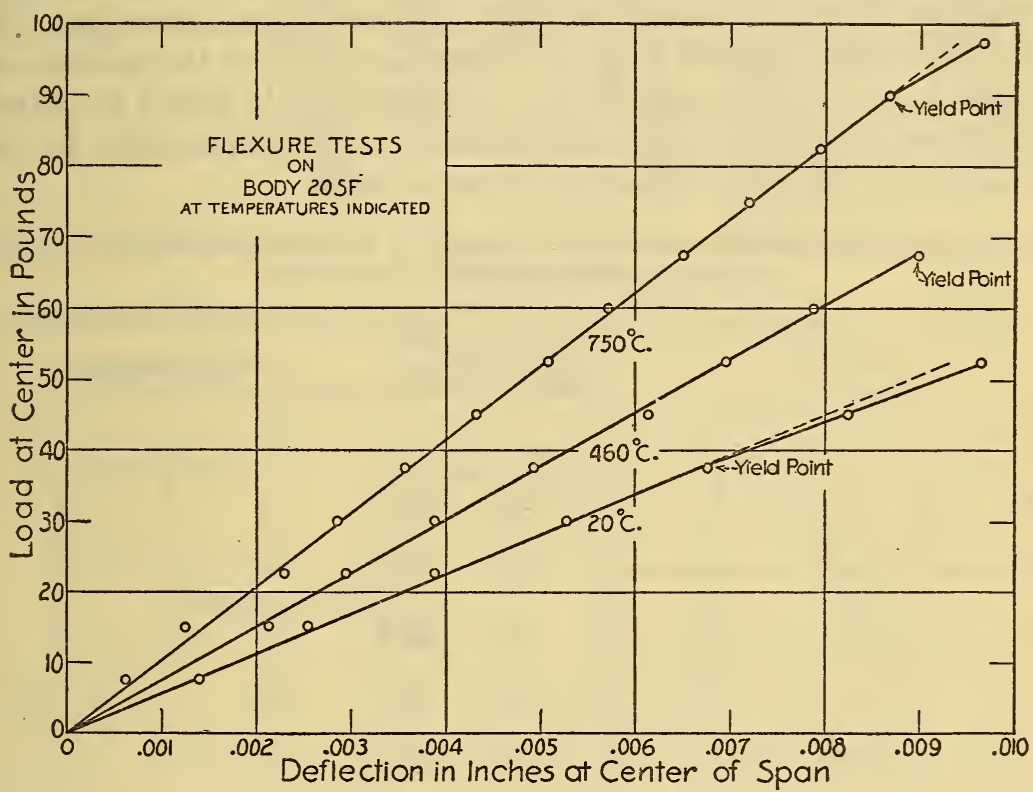

FIGURE 3.-Curves showing the typical stress (load) strain (deformation) relation of a sagger body tested at three temperatures

made from these bodies and at $750^{\circ} \mathrm{C}$. The values obtained on 1 by 1 by 12 inch specimens, using a 10 -inch span are given in Table 2 .

Bodies fired at $1,270^{\circ} \mathrm{C}$.- The modulus of elasticity and transverse breaking strength of 18 bodies, including 2 containing special graded grog sizes, and in addition 8 commercial bodies fired at $1,270^{\circ} \mathrm{C}$. are given in Table 3 . These bodies were tested at $1,000^{\circ} \mathrm{C}$. in addition to the three temperatures specified for bodies fired at $1,230^{\circ} \mathrm{C}$. The composition and order of arrangement of the first 16 bodies in Table 2 are identical with the first 16 bodies in Table 3.

The results indicate that there is a slight tendency for the bodies to show increased transverse breaking strength with increased tem- 
peratures to $1,000^{\circ} \mathrm{C}$., the maximum temperature used in these tests. The same holds true regarding the modulus of elasticity up to $750^{\circ} \mathrm{C}$. At $1,000^{\circ} \mathrm{C}$. the latter property shows a decided decrease. The percentage increase in the modulus of elasticity attending an increase in temperature from 20 to $750^{\circ} \mathrm{C}$. is greater than the corresponding: increase in cross-breaking strength. Figure 4 shows the effect of temperature on the modulus of elasticity of bodies fired at $1,270^{\circ} \mathrm{C}$. The curves are presented in three sections to facilitate examination.

Values for the modulus of rupture determined at approximately $20^{\circ} \mathrm{C}$. for bodies fired at $1,230^{\circ}$ and $1,270^{\circ} \mathrm{C}$. and plotted as in Figure 5 indicate that the ordinary or usual relation exists between transverse strength and modulus of elasticity; that is, the modulus of elasticity is greatest with the greatest strength. These figures also show that the modulus of elasticity increased more rapidly than the modulus of rupture as the temperature of firing was raised. As stated in Report III, ${ }^{8}$ the relationship is only approximate and the explanation for the variations is not evident from the data at hand.

TABLE 5.-Determinations and checks of moduli of elasticity and rupture obtained on sagger bodies at several temperaiures

\begin{tabular}{|c|c|c|c|}
\hline Body No. & $\begin{array}{c}\text { Modulus } \\
\text { of elas- } \\
\text { ticity }\end{array}$ & $\begin{array}{l}\text { Modulus } \\
\text { of rup- } \\
\text { ture }\end{array}$ & Results obtained at- \\
\hline $4 \mathrm{XC}$ & $\left\{\begin{array}{r}1,000 \\
\text { lbs./in. } 2 \\
1,730 \\
1,740\end{array}\right.$ & $\begin{array}{r}\text { Lbs./in. }{ }^{2} \\
1,210 \\
1,215\end{array}$ & \\
\hline 8C.......... & $\begin{array}{l}1,000 \\
1,110\end{array}$ & $\begin{array}{l}510 \\
500\end{array}$ & \\
\hline $10 \mathrm{C}_{-.-}$ & $\begin{array}{l}520 \\
565\end{array}$ & $\begin{array}{l}450 \\
395\end{array}$ & ( Novi Lemperature. \\
\hline $11 \mathrm{C}_{--}$ & $\begin{array}{l}1,340 \\
1,625\end{array}$ & $\begin{array}{l}660 \\
600\end{array}$ & \\
\hline $3 \mathrm{~F}_{--}$ & $\begin{array}{l}3,920 \\
3,500\end{array}$ & $\begin{array}{l}1,770 \\
1,940\end{array}$ & \\
\hline $5 \mathrm{~F}_{---}$ & $\begin{array}{l}3,520 \\
3,560\end{array}$ & $\begin{array}{l}1,970 \\
1,920\end{array}$ & \\
\hline $6 \mathrm{C}_{-}$ & $\left\{\begin{array}{l}1,960 \\
1,960\end{array}\right.$ & $\begin{array}{l}950 \\
920\end{array}$ & $\begin{array}{l}\text { Temperature at which sagger failed in } \\
\text { heat shock test. }\end{array}$ \\
\hline 7C..- & $\begin{array}{l}3,050 \\
3,330\end{array}$ & $\begin{array}{l}1,185 \\
1,355\end{array}$ & \\
\hline $9 \mathrm{C}_{-}$ & $\begin{array}{l}4,400 \\
4,285\end{array}$ & $\begin{array}{l}1,200 \\
1,340\end{array}$ & te \\
\hline $9 \mathrm{~F}_{-.-}$ & $\begin{array}{l}5,920 \\
6,020\end{array}$ & $\stackrel{(a)}{2,320}$ & $750^{\circ} \mathrm{C}$. \\
\hline $13 \mathrm{~F}_{---}$ & $\begin{array}{l}3,100 \\
3,100\end{array}$ & $\begin{array}{l}(a) \\
2,320\end{array}$ & \\
\hline $6 \mathrm{aC}_{-}$ & $\begin{array}{l}1,180 \\
1,200\end{array}$ & $\begin{array}{l}765 \\
760\end{array}$ & \}Room temperature. \\
\hline $6 \mathrm{aC}-\ldots$ & $\begin{array}{l}785 \\
700\end{array}$ & $\begin{array}{l}1,550 \\
1,420\end{array}$ & \} $1,000^{\circ} \mathrm{C}$ \\
\hline
\end{tabular}

a No data obtained.

8 See footnote 1, p. 420. 

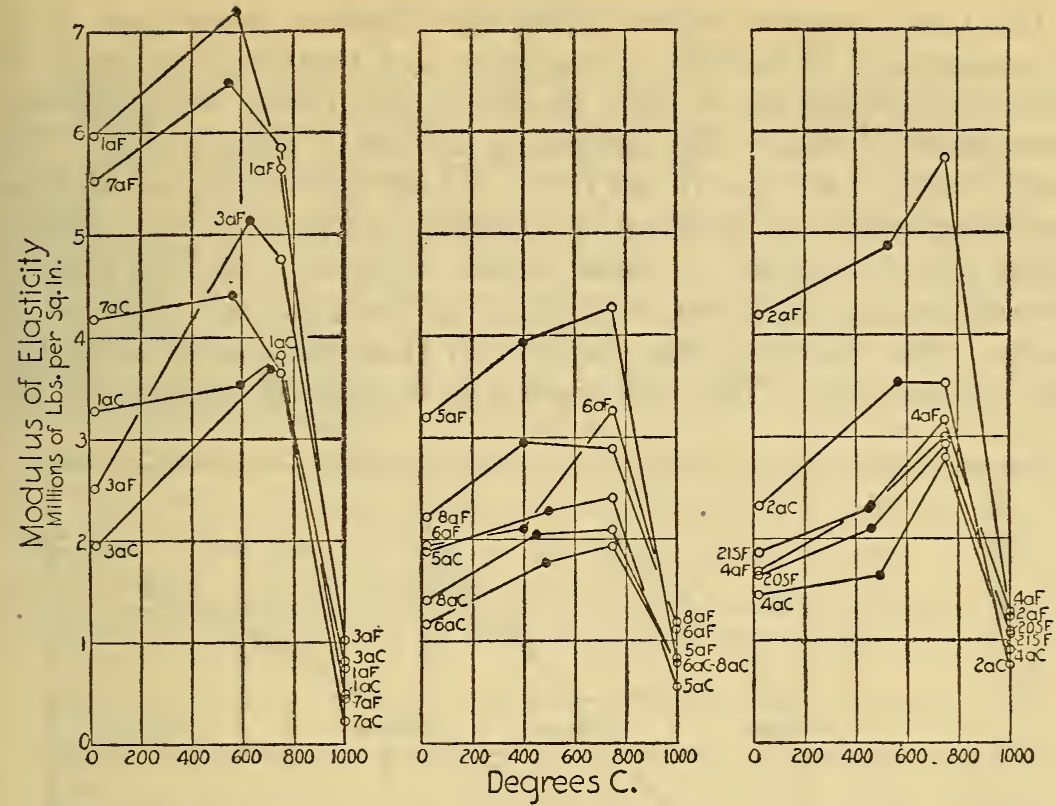

FIGURE 4.-Effect of temperature on the modulus of elasticity of 18 sagger bodies

Filled circles indicate temperatures at which saggers failed in the air-quenching test

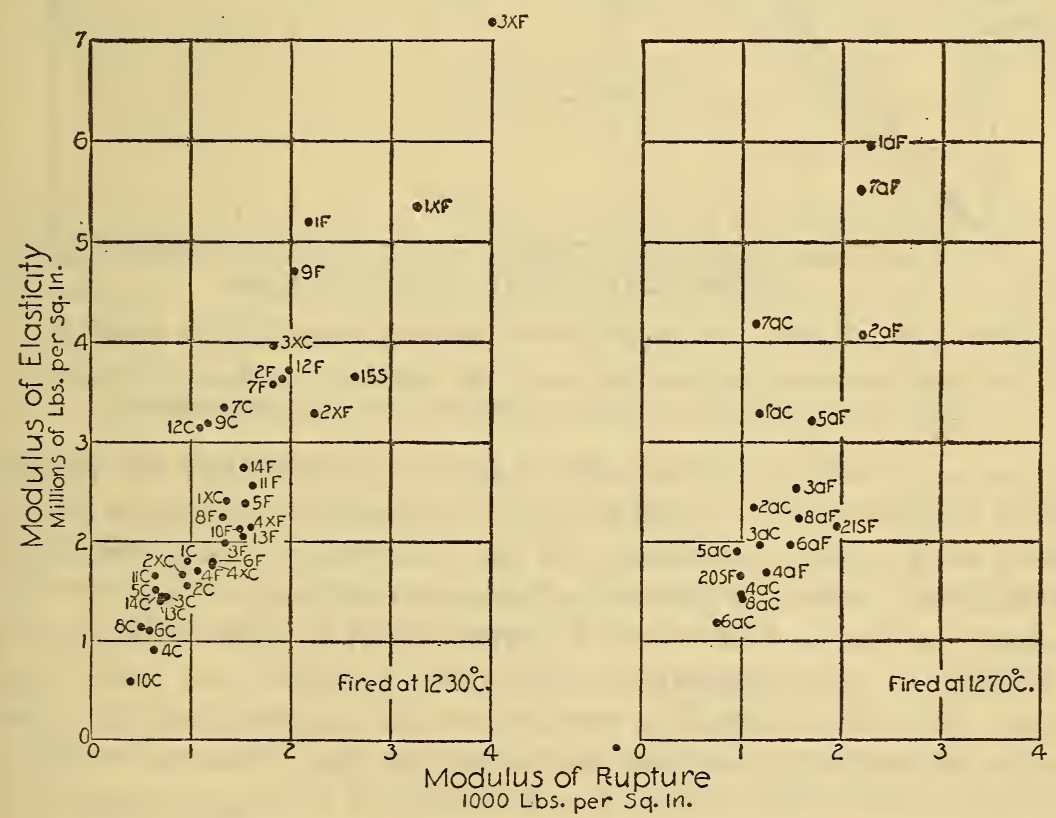

FIGURE 5.-Showing the relation between modulus of elasticity and transverse strength (modulus of rupture) determined at room temperature of sagger bodies fired at either $1,230^{\circ}$ or $1,270^{\circ} \mathrm{C}$. 
The third progress report of this investigation states that check determinations of moduli of elasticity and rupture were made at room temperature on all clay specimens and check determinations were made of three clay specimens at higher temperature. The results varied less than 10 per cent. Check determinations of these same properties were made on 25 specimens referred to in the present report and a number of these values, together with the original determinations, are given in Table 5 to illustrate the variation in results. The results in the majority of these cases also varied less than 10 per cent. The test piece was considered defective if the

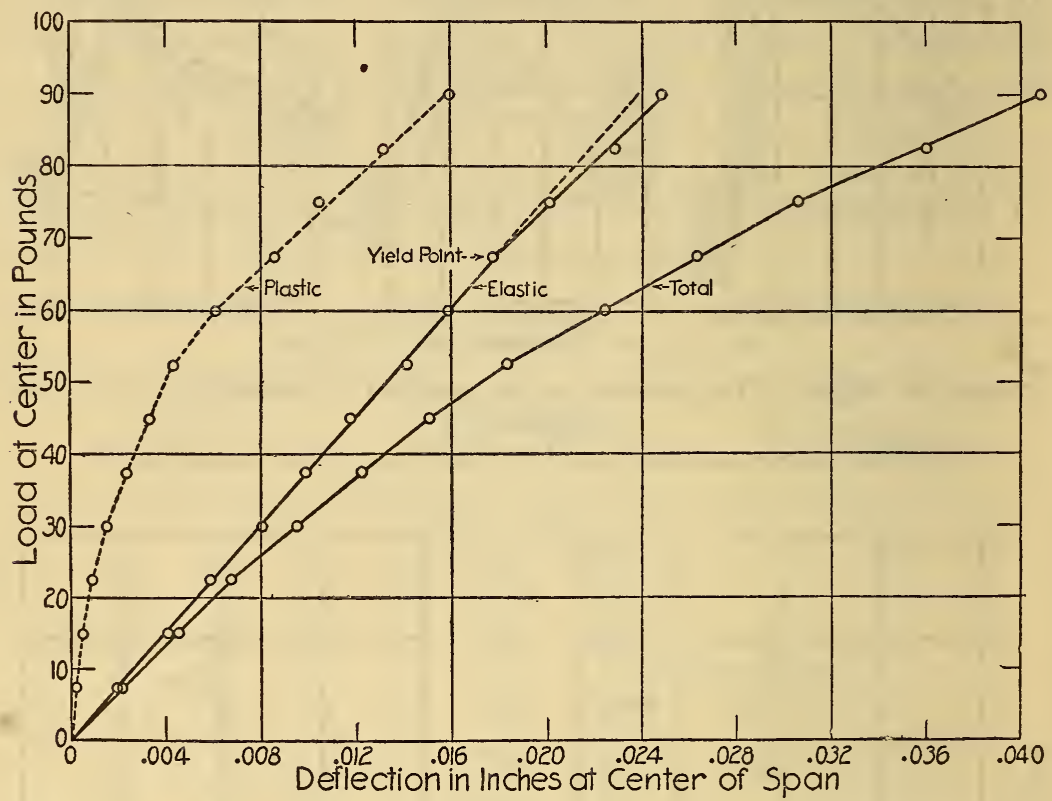

Fradre 6.-Showing the load-deflection curves of body $20 S F$ at $1,000^{\circ} C$.

The upper curve shows the plastic flow or set of the material, the middle curve the elastic deflection, and the lower curve the total deflection at each of the loads indicated

rupture occurred at a point other than at approximately the middle of the 10-inch span. In such cases the necessary data were determined on a second specimen. As has been stated, those specimens of each body tested at three temperatures not greater than $750^{\circ} \mathrm{C}$., exclusive of the test at $1,000^{\circ} \mathrm{C}$., were found to have decreased in flexibility as the temperature was raised at which the tests were made. If the load-deflection curves for these specimens became more nearly vertical with each increase of temperature (thus indicating a decrease in flexibility) this fact was considered as further evidence of the specimens being free from important defects. 


\section{PLASTIC FLOW}

Typical load deflection curves, as obtained at $1,000^{\circ} \mathrm{C}$. for body No. 20SF are shown in Figure 6. The upper curve shows the plastic flow of the material under various loads, the center curve shows the elastic properties, and the lower curve shows the total deflection of the specimen at each of the loads indicated. As stated in Report IV, ${ }^{9}$ the elastic recovery of the material was considered as the difference between the deflection caused by the load and the "set" of the material on removal of this load. The deflections resulting from plastic flow of 24 sagger bodies fired at $1,270^{\circ} \mathrm{C}$. are given in columns 2 and 3 , T'able 6 . The results were obtained at $1,000^{\circ} \mathrm{C}$. and they are the average of increments obtained every five minutes for onehalf hour when using a load of $30 \mathrm{lbs}$./in. ${ }^{2}$, and for one hour when using a load of approximately $120 \mathrm{lbs}$./in. ${ }^{2}$. The load was applied midspan of the 1 by 1 by 12 inch specimens on a 10-inch span. The

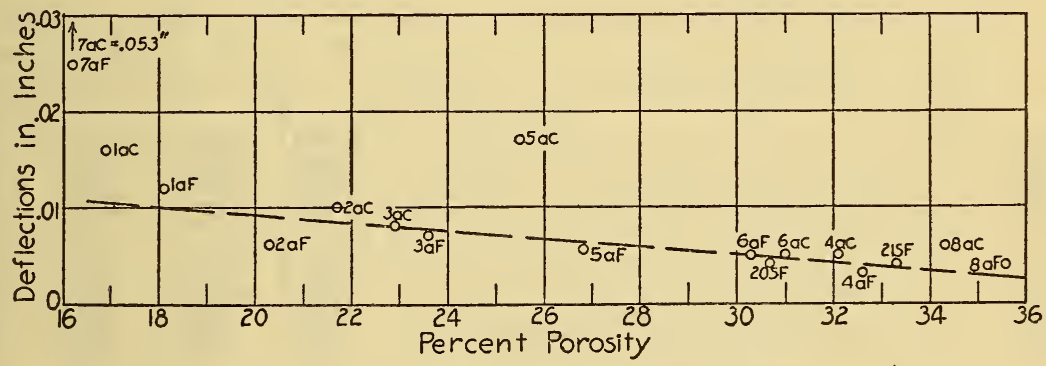

Figure 7.-Effect of porosity on the plastic flow of sagger bodies

values given in column 4 , Table 6 , represent the total plastic deflection, in inches, of the various bodies under a stress of approximately 240 lbs./in. ${ }^{2}$. The values, taken from curves similar to that identified as "plastic" in Figure 6, illustrate the large variation in this property among the various bodies. It is quite possible that an appreciable error may be present in the results obtained with a load of $30 \mathrm{lbs} . / \mathrm{in}^{2}$ because of the limit of accuracy of the apparatus used.

For convenience the porosities of the bodies fired at $1,270^{\circ} \mathrm{C}$. are shown in column 5 , Table 6 , with the plastic-flow data. These values plotted in Figure 7 indicate that, as illustrated by one of a number of lines which may be drawn through the plotted points, there may be a tendency for the plastic flow (column 4) of the body to decrease as the porosity of the body becomes greater when determined under the conditions stated. ${ }^{10}$ Such a relation might be expected, since the

\footnotetext{
${ }^{\circ}$ See footnote 1, p. 420.

10 This relationship would possibly become more exact if deflection determinations had been made on several specimens instead of only one, as in the present study. The porosity given is the average of five
} determinations. 
fluxes introduced by the clays in a dense sagger body have a greater opportunity for reaction during firing than if present in a less dense body.

TABLE 6.-Plastic flow data determined on sagger bodies fired at $1,270^{\circ} \mathrm{C}$.

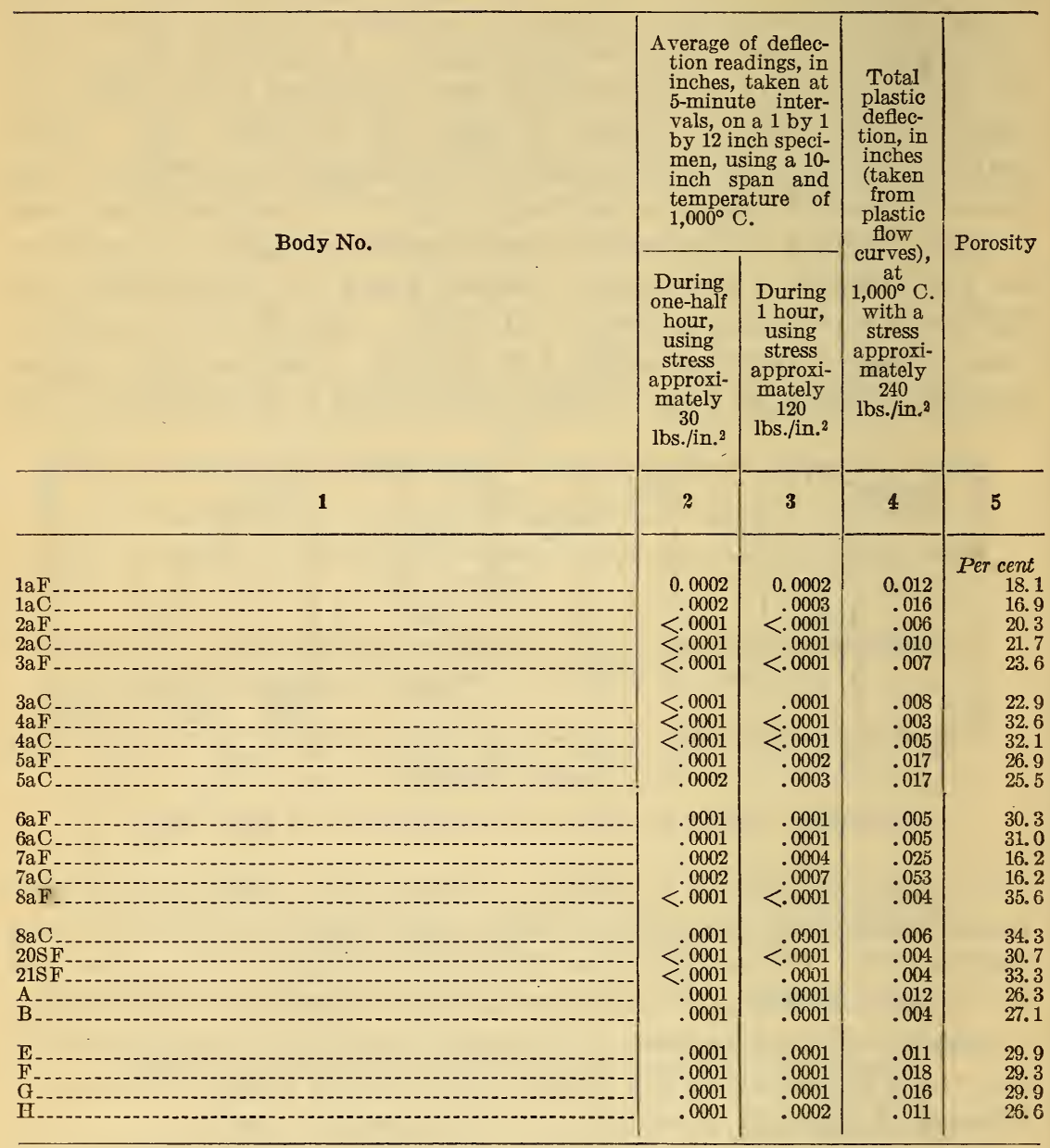

Bodies $7 \mathrm{aF}$ and $7 \mathrm{aC}$, although showing good resistance in the heatshock test, would undoubtedly prove unsatisfactory for sagger purposes because of a comparatively high plastic flow at $1,000^{\circ} \mathrm{C}$.

\section{AIR QUENCHING OR DUNTING TESTS}

The results, showing the average temperature of failure of five small oval saggers in the heat-shock test, are given in Table 2 for the saggers fired at $1,230^{\circ} \mathrm{C}$. and in Table 3 for the saggers fired at $1,270^{\circ} \mathrm{C}$. Table 3 also contains the results of the tests on saggers prepared from commercial sagger bodies furnished by several potteries. 
B. S. Journal of Research, RP104

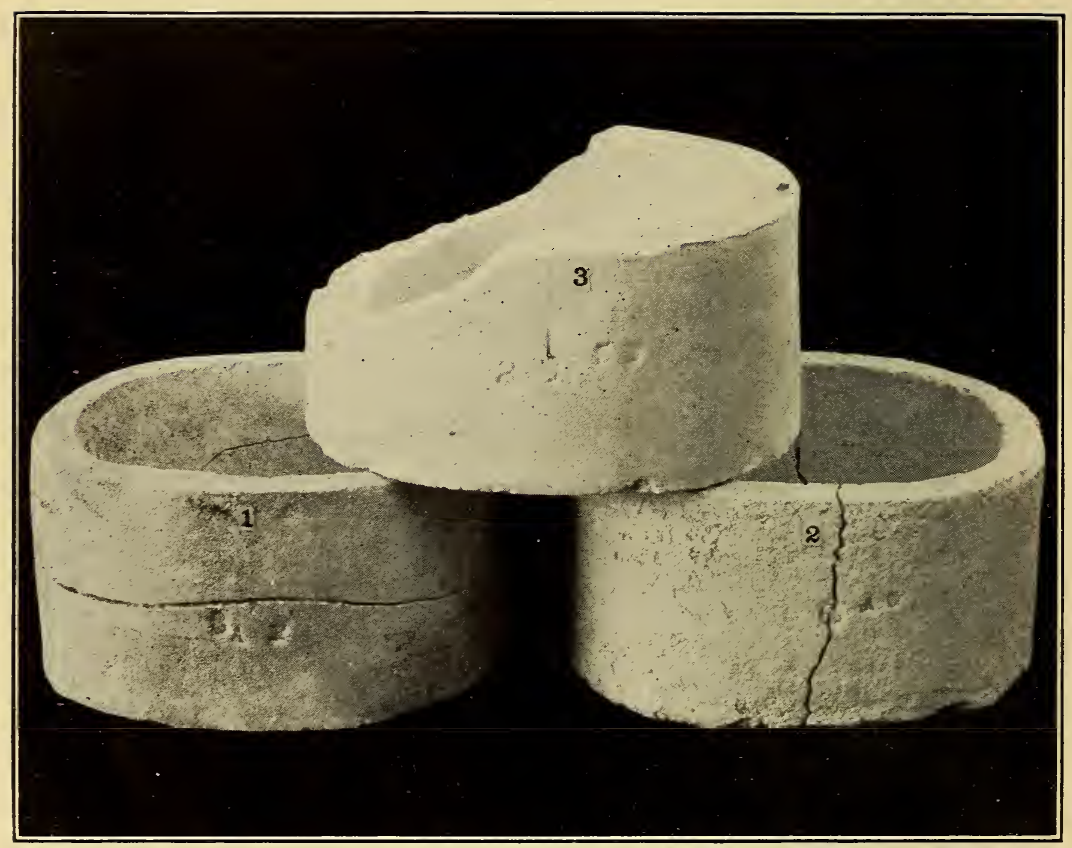

FIGURE 8.-Saggers illustrating the three types of failures which occurred in the thermal shock test 
The types of failure encountered during the testing of these saggers are shown in Figure 8. Sagger No. 1 illustrates a failure found only in saggers prepared from bodies containing the fine grog sizes. Sagger No. 2 shows the type of failure which was the most prevalent. The third type of failure, illustrated by sagger No. 3, occurred only in a few cases.

The average, the maximum, and the minimum temperatures of failure and porosities of the saggers prepared from the first 16 bodies listed in Tables 2 and 3 are as follows:

\begin{tabular}{|c|c|c|c|c|}
\hline & \multicolumn{4}{|c|}{ Temperature of failure of saggers fired at- } \\
\hline & \multicolumn{2}{|c|}{$1,230^{\circ} \mathrm{C}$. } & \multicolumn{2}{|c|}{$1,270^{\circ} \mathrm{C}$. } \\
\hline & $\begin{array}{l}\text { Fine } \\
\text { grog }\end{array}$ & $\begin{array}{l}\text { Coarse } \\
\text { grog }\end{array}$ & $\begin{array}{l}\text { Fine } \\
\text { grog }\end{array}$ & $\begin{array}{l}\text { Coarse } \\
\text { grog }\end{array}$ \\
\hline $\begin{array}{l}\text { Maximum } \\
\text { Minimum }\end{array}$ & $\begin{array}{l}760 \\
415\end{array}$ & $\begin{array}{l}860 \\
500\end{array}$ & $\begin{array}{l}400 \\
630\end{array}$ & $\begin{array}{l}450 \\
710\end{array}$ \\
\hline A verage & 580 & 675 & 495 & 540 \\
\hline Porosity & 26.2 & $\overline{26.2}$ & $\overline{25.4}$ & $\overline{25.1}$ \\
\hline
\end{tabular}

These average values show that the coarse-grogged saggers resist thermal shock to a considerably greater extent than the fine-grogged saggers, although this difference is more pronounced in the saggers fired at $1,230^{\circ} \mathrm{C}$. than those fired at $1,270^{\circ} \mathrm{C}$. These results also show that the resistance to thermal shock decreases noticeably with the increased temperature of firing of saggers. Furthermore, a comparison of the average porosities of the fine and coarse grogged bodies indicates that, within the ranges of grog sizes and temperatures of firing studied, the porosity as determined does not give a true indication of the pore structure of the body.

Sagger bodies Nos. 9F, 9C, 10F, 10C, 12F, 12C, 13F, and $13 \mathrm{C}$ were prepared from two clays each and grog made from only one of the clays used in the respective bodies. The grog used in sagger mixes $9 \mathrm{~F}, 9 \mathrm{C}, 12 \mathrm{C}$, and $12 \mathrm{~F}$ was prepared from that clay in the mix having the lower porosity after firing at $1,230^{\circ} \mathrm{C}$., whereas bodies $10 \mathrm{~F}, 10 \mathrm{C}, 13 \mathrm{~F}$, and $13 \mathrm{C}$ contained grog prepared from that clay in the body having the higher porosity after firing at $1,230^{\circ} \mathrm{C}$. Furthermore, bodies Nos. $7 \mathrm{~F}$ and $7 \mathrm{C}$ contain the same clays as $9 \mathrm{~F}$ and $9 \mathrm{C}$ and bodies $13 \mathrm{~F}$ and $13 \mathrm{C}$ contain the same clays as $14 \mathrm{~F}$ and $14 \mathrm{C}$. The results obtained in the thermal shock test indicate that saggers prepared with grog having a relatively high porosity show greater resistance to heat shock than do saggers containing grog having a low porosity. A summary of the average values obtained on the fine and coarse grogged bodies as well as those of the clays are as follows:

$64338^{\circ}-29-7$ 
Average temperature of failure of saggers

\begin{tabular}{|c|c|c|c|c|}
\hline \multirow{2}{*}{ Body Nos. } & \multirow{2}{*}{ Type of grog in body } & \multicolumn{2}{|c|}{ Prepared from- } & \multirow{2}{*}{ Remarks } \\
\hline & & $\begin{array}{l}\text { Single } \\
\text { clays }\end{array}$ & $\begin{array}{l}\text { Blended } \\
\text { clays }\end{array}$ & \\
\hline $\begin{array}{l}7 \mathrm{~F} \text { and } 7 \mathrm{C} \\
9 \mathrm{~F} \text { and } 9 \mathrm{C} \\
10 \mathrm{~F} \text { and } 10 \mathrm{C} \\
12 \mathrm{~F} \text { and } 12 \mathrm{C} \\
13 \mathrm{~F} \text { and } 13 \mathrm{C} \\
14 \mathrm{~F} \text { and } 14 \mathrm{C}\end{array}$ & $\begin{array}{l}\text { Equal parts high and low porosity } \\
\text { Low porosity } \\
\text { High porosity } \\
\text { Low porosity } \\
\text { High porosity } \\
\text { Equal parts high and low porosity }\end{array}$ & $\begin{array}{l}\circ C . \\
665 \\
665 \\
390 \\
570 \\
435 \\
435\end{array}$ & $\begin{array}{r}\circ{ }^{\circ} . \\
650 \\
605 \\
520 \\
575 \\
655 \\
575\end{array}$ & $\begin{array}{l}\text { Same clays in bodies } 7 \\
\text { and } 9 . \\
\text { Same clays in bodies } 13 \\
\text { and } 14 .\end{array}$ \\
\hline
\end{tabular}

Bodies Nos. 10 and 12, although compounded with different clays, illustrate the effect on the resistance to thermal shock of saggers containing either dense or porous grog. As shown, the average of the two failing temperatures of the saggers made from each clay used in body No. 10 was $390^{\circ}$ C.; the saggers from the blended clays and a porous grog showed greatly increased resistance to failure. The temperature of failure in this case was $520^{\circ} \mathrm{C}$. In the case of body No. 12 the average of the two failing temperatures of the saggers prepared from each clay was $570^{\circ} \mathrm{C}$., whereas the average of the failing temperatures of saggers prepared from the blended clays and a dense grog was $575^{\circ}$ C. Furthermore a comparison of the results obtained on body No. 7 with body No. 9 and also on body No. 13 with body No. 14 indicates that the sagger containing the greater percentage of porous grog shows the greatest resistance to heat shock.

Body No. $11 \mathrm{~F}$ and body No. $11 \mathrm{C}$ are described in the section on "Linear thermal expansion." The average of the two failing temperatures of the saggers made from each of the constituent clays was $465^{\circ}$ C., the average of the two failing temperatures of saggers prepared from the blended clays was $645^{\circ} \mathrm{C}$. The reaction which occurred, incident to the burning of these two blended clays caused an unusual improvement in the thermal expansion of the blended clay sagger bodies (see fig. 2) and undoubtedly was partially the cause of the excellent resistance to failure shown by the saggers in the heat-shock test.

Bodies Nos. $1 \mathrm{XF}$ to $4 \mathrm{XC}$, inclusive, representing the eight sagger mixes compounded with grog materials burned at $775^{\circ} \mathrm{C}$. contain clays of the same laboratory key numbers as bodies Nos. 5, 6, 7, and 4, respectively. As indicated by the results in Table 2, this method of preparing grog does not improve the resistance of saggers to thermal shock. The grog is sufficiently soft to permit its disintegration during pugging of the sagger body which, in consequence, causes a body of finer texture with increased modulus of elasticity. At the same time the heat conductivity of the sagger is probably decreased, which also would be a factor in decreasing the resistance to failure in the heat-shock test. 
Body $15 \mathrm{~S}$, which contains the grog and dust passing an 80-mesh sieve, was included to show the effect of extremely fine grog on the resistance to failure of a sagger in the thermal shock test. Both the porosity and transverse strength of this body are high, and the saggers failed at or below $350^{\circ} \mathrm{C}$., an exceptionally low temperature. Body No. $8 \mathrm{~F}$ containing the same body composition, but with graded grog, failed at $450^{\circ} \mathrm{C}$.

Body 21SF (Table 3) was prepared from the same clays as bodies Nos. $4 \mathrm{aF}$ and $4 \mathrm{aC}$, but the grading of the grog was varied as shown in the section on "Sagger body compositions." Although body 21SF contained 40 per cent of grog passing an 80 and retained on a 200mesh sieve, the sagger failed in the air-quenching test at approximately the same temperature as body $4 \mathrm{aF}$ which contained no grog finer than that retained on an 80-mesh sieve. This would indicate that properly graded grog sizes, even as fine as those used in body $21 \mathrm{SF}$, may be used to advantage to increase the mechanical strength of saggers.

Body No. 20SF was prepared from the same clays as bodies Nos. $6 \mathrm{aF}$ and $6 \mathrm{aC}$, but with a fairly wide range of specially graded grog sizes. The saggers made from body $20 \mathrm{SF}$ failed at $460^{\circ} \mathrm{C}$. in the heat-shock test, the approximate average failing temperature of saggers made from bodies $6 \mathrm{aF}$ and $6 \mathrm{aC}$ which failed at $400^{\circ}$ and $590^{\circ}$ C., respectively. The modulus of elasticity and transverse strength of body $20 \mathrm{SF}$ determined at $20^{\circ} \mathrm{C}$. is also approximately the average of that obtained on bodies $6 \mathrm{aF}$ and $6 \mathrm{aC}$. According to the data given in Table 6, the plastic flow of body 20SF under a load of $240 \mathrm{lbs} . / \mathrm{in} .^{2}$ is slightly less than that of either body $6 \mathrm{aF}$ or $6 \mathrm{aC}$. It would, therefore, appear from the limited data available that the use of grog, graded into as many as six sizes, is of no outstanding advantage in a sagger body when compared with bodies using three sizes of graded grog.

The data show that the individual saggers in any one set of five fired at $1,230^{\circ} \mathrm{C}$. failed in the quenching test within $100^{\circ} \mathrm{C}$. or less of one another in 32 out of a total of 37 bodies, and those fired at $1,270^{\circ} \mathrm{C}$. failed within $75^{\circ} \mathrm{C}$., or less, of one another in 23 out of a total of 26 bodies.

\section{RELATION BETWEEN POROSITY AND DUNTING}

As indicated by the following table of averages of temperatures at which saggers failed in the air-quenching test and the porosities of the fired sagger bodies, it is advantageous to keep the porosities of these bodies below 25 per cent. The bodies were separated into two 
groups, according to whether the porosity was greater or less than 25 per cent:

\begin{tabular}{|c|r|r|}
\hline $\begin{array}{c}\text { Saggers } \\
\text { fired at- }\end{array}$ & $\begin{array}{r}\text { Average } \\
\text { tempera- } \\
\text { ture of } \\
\text { failure }\end{array}$ & Porosity \\
\hline$\circ C$ & ${ }^{\circ} C$ & Per cent \\
1,230 & 675 & 20.7 \\
1,270 & 565 & 31.2 \\
& 590 & 19.5 \\
455 & 31.2 \\
\hline
\end{tabular}

Sufficient data are not at hand to warrant any conclusions as to the lowest permissible porosity compatible with the longest sagger life.

\section{EFFECT OF THERMAL EXPANSION ON DUNTING}

Grouping the sagger bodies fired at $1,230^{\circ} \mathrm{C}$. into two classes according to whether saggers prepared from them failed at temperatures above or below $600^{\circ} \mathrm{C}$. and averaging the temperatures at which they failed as well as the coefficients of expansion of each group from 20 to $250^{\circ}$ C. gives the following:

\begin{tabular}{|c|c|c|}
\hline Group & $\begin{array}{c}\text { Average } \\
\text { failing } \\
\text { tempera- } \\
\text { ture }\end{array}$ & $\begin{array}{c}\text { A verage } \\
\text { coeffi- } \\
\text { cient of } \\
\text { expansion }\end{array}$ \\
\hline $\begin{array}{l}\text { I--- } \\
\text { II-- }\end{array}$ & $\begin{array}{c}{ }^{\circ} C . \\
\quad 695 \\
525\end{array}$ & $\begin{array}{r}\times 10^{-6} \\
6.1 \\
8.2\end{array}$ \\
\hline
\end{tabular}

\section{MODULUS OF ELASTICITY, EXPANSION, TRANSVERSE STRENGTH, POROSITY, AND RESISTANCE TO DUNTING}

An empirical relation, combining the three factors (1) modulus of elasticity, (2) linear thermal expansion, and (3) transverse strength, which was suggested as indicating the relative resistance to failure due to thermal shock, was given in Report III. ${ }^{11}$ The sagger bodies referred to in that report contained grog which had been graded alike for all mixtures. Substituting the data obtained in the present work in that formula, it was found that the factors $R$ so computed did not satisfactorily indicate the relative resistance to thermal shock actually obtained. Changing the formula to include the porosity of the body overcame this discrepancy. This may be from the fact that the thermal conductivity of the body probably has a significant effect on its resistance to heat shock. Since it is reasonable to assume that pores affect conductivity, porosity might be introduced into the for- 
mula and more consistent values of $R$ obtained. Consequently the formula is altered as follows:

$$
R=\frac{M}{E \cdot e \cdot P}
$$

where

$R=$ factor indicating relative resistance of a sagger to failure, $M=$ modulus of rupture,

$E=$ modulus of elasticity,

$e=$ coefficient of linear thermal expansion,

$P=$ porosity.

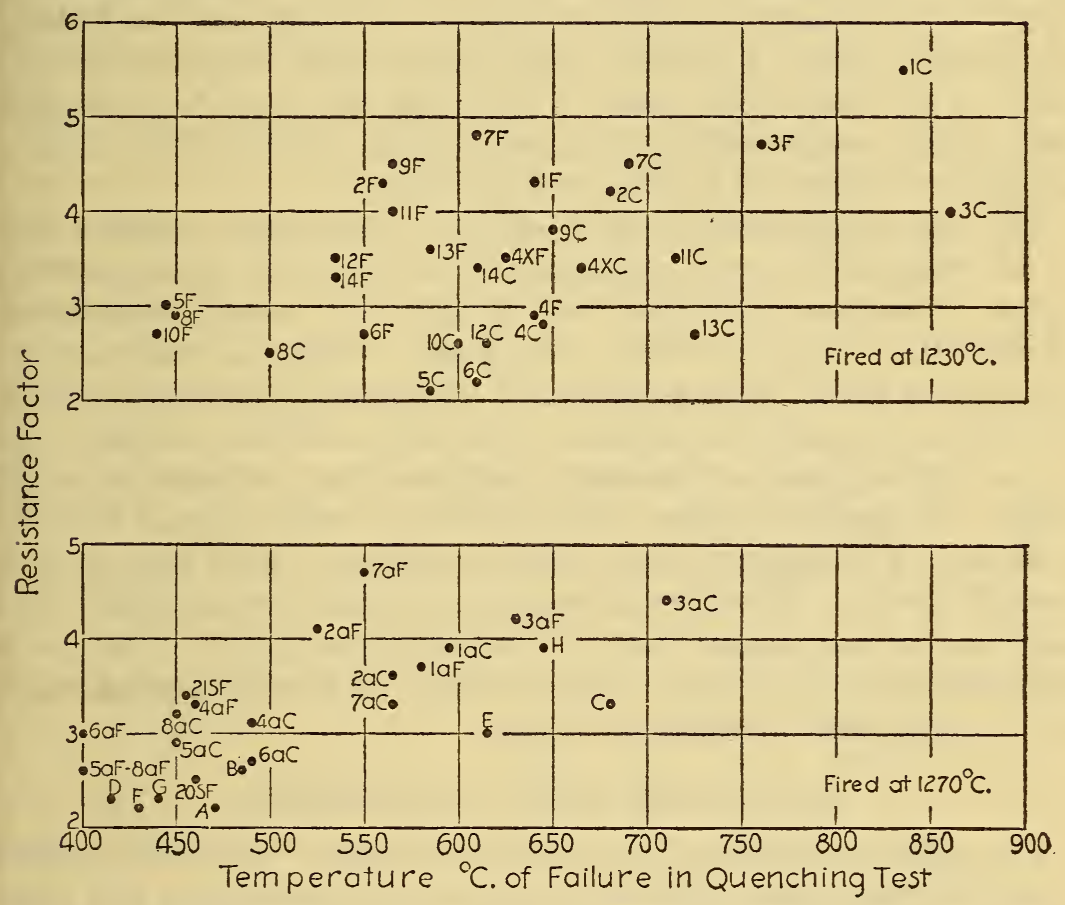

FIGURE 9.-Showing the resistance $(R)$ of saggers, fired at either $1,230^{\circ}$ or $1,270^{\circ} C$., to dunting

Data used in computing the resistance factor were determined at $20^{\circ} \mathrm{C}$., and the average coefficient of expansion was taken from $20^{\circ} \mathrm{C}$. to the temperature at which the saggers failed in the air-quenching test

The resistance factors $R$, computed from the moduli of elasticity and rupture and porosity determined at $20^{\circ} \mathrm{C}$. and the average coefficient of expansion for the range from $20^{\circ} \mathrm{C}$. to the temperature at which the saggers failed in the heat shock test, are given in Tables 2 and 3 for the saggers fired at 1,230 and $1,270^{\circ}$ C., respectively. $R$ plotted against the failing temperature of the saggers in Figure 9 shows, in general, that the greater the numerical value of this factor the greater the resistance of the sagger body to heat shock. Values for $R$ computed from the moduli of elasticity and rupture determined 
at either $750^{\circ} \mathrm{C}$. or the failing temperatures of the saggers in the heatshock test and the average coefficient of expansion between 20 and $600^{\circ} \mathrm{C}$. give a similar relation. Although the relation between the calculated resistance $R$ and the life of the sagger as indicated by the quenching test is not as close as may be desired, the trend of the points in Figure 9 indicates such a relation. The irregularities in the trend of the points may be partially accounted for by the differences in fired properties resulting from unavoidable variations in the heat treatment which the saggers and specimen bars received. This difference in heat treatment was especially apparent in the case of the material fired at $1,230^{\circ} \mathrm{C}$., the resistance factors for which show the greater irregularity. In addition, other properties, such as thermal conductivity and modulus of elasticity in shear, which have not been determined in these studies, undoubtedly have an appreciable effect on the resistance of saggers to failure in the thermal shock test.

The resistance factors for the majority of the bodies fired at $1,230^{\circ}$ C. are grouped near the approximate center of the upper graph in Figure 9 , whereas the bodies fired at $1,270^{\circ} \mathrm{C}$. have grouped themselves to the bottom left of the lower graph. This illustrates that the firing at the higher temperature has a detrimental effect on the resistance of the sagger to heat shock. Since repeated firings at the same temperature appear to have similar effects on the properties of sagger bodies ${ }^{12}$ as firing at higher temperatures, it would appear that the resistance of a sagger to heat shock is decreased after each heating cycle in service. In the lower graph the factor for body $7 \mathrm{aF}$ is an exception to the general trend for bodies in that group. The factor indicates a relatively high resistance while the temperature at which the saggers failed is comparatively low.

\section{EXTREME FIBER DEFORMATION}

The maximum deformation of the extreme fiber ${ }^{13}$ is the deformation under the maximum stress at mid span along the upper and lower surfaces of the specimen. The outer fiber deformation values of the fired sagger bodies at various temperatures given in Tables 2 and 3 (columns headed "Computed outer fiber strain") are all computed by the following formula:

$\left.\begin{array}{c}\text { Maximum elongation per } \\ \text { unit length, per cent }\end{array}\right\}=\frac{\text { modulus of rupture }}{\text { modulus of elasticity }} \times 100$

The values so obtained are an expression of the approximate flexibility of the materials. An examination of these data indicates that the flexibility of the bodies decreased (1) with increased temperature

\footnotetext{
12 Data on the effect of repeated firing of sagger clays are published in Report I. See footnote 1, p. 420.

${ }^{13}$ A detailed discussion on maximum deformation (elongation) and why it is desirable to use the secant modulus of elasticity when computing the strain values at $1,000^{\circ} \mathrm{C}$. may be found in Report IV of this investigation. See footnote 1, p. 420 .
} 
of firing and (2) as the temperature of the material is raised until plastic flow commences under the load applied.

\section{COMMERCIAI SAGGER BODIES}

The laboratory identification letters for the commercial sagger mixes are $\mathrm{A}$ to $\mathrm{H}$, inclusive. The properties of the bodies as determined on specimen bars and experimental saggers fired at $1,270^{\circ} \mathrm{C}$. (cone $11 \frac{1}{2}-12$ ) are given in Table 3 . The resistance factors $R$, of these mixes, given in Table 3 , are included with the others plotted in Figure 9. The resistance to failure in the thermal shock test of saggers, prepared from bodies $\mathrm{C}, \mathrm{E}$, and $\mathrm{H}$, is noticeably greater than that of the saggers prepared from the other five bodies. The modulus of elasticity of each of these three bodies is less and the computed outer fiber strain is greater than those of the remaining bodies. The increased resistance to failure of the saggers made from these bodies is probably due to these favorable factors. The properties of these bodies appear as a whole to be similar to the properties of the coarse grogged experimental bodies prepared in the laboratory. Largely, because of the coarse sizes of grog used in the bodies, the fired strength and the modulus of elasticity are low. It is believed that a low modulus of elasticity is desirable in a sagger body.

Bodies $\mathrm{C}$ and $\mathrm{D}$ were furnished by the same manufacturer. Body C, developed after a study of experimental sagger bodies, shows a great improvement in resistance to thermal shock when compared with body $\mathrm{D}$. The modulus of elasticity of body $\mathrm{D}$ is approximately twice that of body $\mathrm{C}$ and is probably one of the most significant properties affecting dunting of saggers in the heat shock test at comparatively low temperatures. These data are of especial interest since they demonstrate that increased life of saggers, due to their greater resistance to thermal shock, may be obtained by altering the sagger mixes in such a manner as to produce a structure of the fired ware having those properties effective in prolonging the life.

\section{SUMMARY}

Five small saggers were made from each of 23 experimental bodies and 10 small saggers were made from each of 16 bodies. The 39 bodies were prepared from 15 different clays and grogs made from these clays. The majority of the bodies were made of two clays and grogs prepared from these clays, each combination of clays being made into two bodies, one prepared with coarse-graded grog and the other with comparatively fine-graded grog. The saggers were tested for resistance to heat.shock after firing at either $1,230^{\circ}$ or $1,270^{\circ} \mathrm{C}$. Specimen bars were made to correspond with each set of saggers and fired simultaneously with the saggers. These bars were used for determining the linear thermal expansion from $20^{\circ}$ to $1,000^{\circ} \mathrm{C}$., porosity, 
moduli of elasticity, and rupture at room and elevated temperatures, and plastic flow at $1,000^{\circ} \mathrm{C}$. In addition, saggers and specimens from eight raw sagger bodies furnished by potteries were fired at $1,270^{\circ} \mathrm{C}$. and tested.

The linear thermal expansion of the bodies fired at $1,230^{\circ} \mathrm{C}$. shows that they may be classed as follows into three groups according to the expansion: That of the body may be (1) greater than that of either clay, (2) approximately equal to the average of that of the clays, (3) approximately equal to the clay having the lower expansion. A comparison of the expansion of the bodies prepared with the coarse sizes of grog against those prepared with the finer sizes of grog shows that in the majority of cases the coarse-grogged bodies have the lower expansion. A comparison of the thermal expansion of the sagger bodies with those of the clays contained in the bodies shows that of the total of 15 combinations, 12 had more desirable expansions than either one or both of the constituent clays.

A direct relation between modulus of elasticity and transverse strength of the bodies is shown. The modulus of elasticity increased more rapidly than the strength when the bodies were $(a)$ fired at $1,270^{\circ} \mathrm{C}$. as compared with $1,230^{\circ} \mathrm{C}$., and $(b)$ tested at increasing temperatures ranging from $20^{\circ}$ to $750^{\circ} \mathrm{C}$.

A relation between porosity and plastic flow of the bodies under load at $1,000^{\circ} \mathrm{C}$. is indicated.

The results show that the resistance of saggers to thermal shock (1) decreases with increased temperature of firing of saggers, (2) is generally less for bodies having a porosity greater than 25 per cent when compared with those having a porosity less than 25 per cent, (3) is greater for saggers prepared with grog having a relatively high porosity than those containing grog of low porosity, and (4) is greater for bodies having a comparatively small and uniform rate of expansion below $250^{\circ} \mathrm{C}$.

A study of the data indicates that the best sagger bodies found in this preliminary experimental study are those having the following properties: (1) Low modulus of elasticity, (2) high transverse strength, (3) porosity below 25 per cent, and (4) low and preferably uniform thermal expansion from $20^{\circ}$ to $250^{\circ} \mathrm{C}$. In addition, it was found that clays of low refractoriness may sparingly and advantageously be used to increase sagger life and that properties stated as (1) and (2) may be partially controlled by grading of grog sizes.

The modulus of elasticity, transverse strength, porosity and coefficient of expansion may be combined into an empirical formula which will give indications of the probable life of a sagger when subjected to repeated thermal shock.

WAShington, January 9, 1929. 